\title{
The Climate Change Challenge: Linking Vulnerability, Adaptation, and Mitigation
}

Citation for published version (APA):

Martens, P., McEvoy, D., \& Chang, C. (2009). The Climate Change Challenge: Linking Vulnerability, Adaptation, and Mitigation. Current Opinion in Environmental Sustainability, 1(1), 14-18.

https://doi.org/10.1016/j.cosust.2009.07.010

Document status and date:

Published: 01/01/2009

DOI:

10.1016/j.cosust.2009.07.010

Document Version:

Publisher's PDF, also known as Version of record

Document license:

Taverne

Please check the document version of this publication:

- A submitted manuscript is the version of the article upon submission and before peer-review. There can be important differences between the submitted version and the official published version of record.

People interested in the research are advised to contact the author for the final version of the publication, or visit the DOI to the publisher's website.

- The final author version and the galley proof are versions of the publication after peer review.

- The final published version features the final layout of the paper including the volume, issue and page numbers.

Link to publication

\footnotetext{
General rights rights.

- You may freely distribute the URL identifying the publication in the public portal. please follow below link for the End User Agreement:

www.umlib.nl/taverne-license

Take down policy

If you believe that this document breaches copyright please contact us at:

repository@maastrichtuniversity.nl

providing details and we will investigate your claim.
}

Copyright and moral rights for the publications made accessible in the public portal are retained by the authors and/or other copyright owners and it is a condition of accessing publications that users recognise and abide by the legal requirements associated with these

- Users may download and print one copy of any publication from the public portal for the purpose of private study or research.

- You may not further distribute the material or use it for any profit-making activity or commercial gain

If the publication is distributed under the terms of Article $25 \mathrm{fa}$ of the Dutch Copyright Act, indicated by the "Taverne" license above, 


\section{The climate change challenge: linking vulnerability, adaptation, and mitigation Pim Martens, Darryn McEvoy and Chiung Chang}

Climate change is emerging as one of the major challenges facing scientific and policy communities. The authors argue that its inherent complexity will ultimately require a much more integrated response scientifically to better understand multiple causes and impacts, as well as at the scientific-policy interface where new forms of engagement between scientists, policymakers, and wider stakeholder communities can make a valuable contribution to more informed climate policy and practice. While scientific research and policy debate is shifting from one of problem-framing to new agendas that are much more concerned with implementation, the improvement of assessment methodologies from a inter- and transdisciplinary perspective, and the reframing of current scientific understanding with regards mitigation, adaptation, and vulnerability, a critical element of responding to the climate change challenge will be to ensure the translation of these new scientific insights into innovative policy and practice 'on the ground'.

\section{Addresses}

International Centre for Integrated Assessment and Sustainable Development (ICIS), Maastricht University, PO Box 616, 6200 MD Maastricht, The Netherlands

Corresponding author: Martens, Pim

(p.martens@maastrichtuniversity.nl), McEvoy, Darryn (d.mcevoy@maastrichtuniversity.nl) and Chang, Chiung (chiung.chang@maastrichtuniversity.nl)

Current Opinion in Environmental Sustainability 2009, 1:14-18

This review comes from the inaugural issues

Edited by Rik Leemans and Anand Patwardhan

Available online 21st August 2009

$1877-3435 / \$$ - see front matter

(C) 2009 Elsevier B.V. All rights reserved.

DOI 10.1016/j.cosust.2009.07.010

\section{Introduction}

The consequences of rapid and substantial humaninduced global climate change could be far-reaching, even leading senior commentators such as Sir David King to label it as one of the greatest threats facing future societies. ${ }^{a}$ Until very recently scientific and policy emphasis has focused on mitigation efforts, that is the reduction of anthropogenic greenhouse gas emissions.

\footnotetext{
${ }^{a}$ http://news.bbc.co.uk/2/hi/science/nature/3381425.stm.
}

However, the success of global mitigation initiatives to date is questionable and the impact of ever more stringent emission control programs could potentially have enormous social consequences. The efficiency of such action is also highly debatable. While the characteristic of prompt costs and delayed benefits has resulted in early research which has concentrated for the most part on 'top down' analyses of the cost-effectiveness of various greenhouse gas abatement strategies, little effort has been expended on the exploration of the interactions among the various elements of the climate problem, on a systematic evaluation of climate stabilization benefits or on the costs of adapting to a changed climate, let alone an integration of different approaches. Crucially, these studies also do not assist decision-makers with the identification of climate change policy objectives; they only address the costs of meeting various abatement targets and the efficacy of different strategies.

More integrated climate strategies will be required to incorporate a wider range of mitigation, adaptation, and vulnerability considerations, with responses also needing to be more closely aligned with the objectives of other non-climate policy realms $[1,2,13]$. In this regard, there is increasing recognition that as policy evolves, new windows of opportunity may also emerge which allow for the articulation of integrated options for long-term policy on climate change mitigation and adaptation, as well as the building of local adaptive capacity and resilience in order to reduce vulnerability to climate change and variability [9]. Ultimately, a coherent response will require consideration of all the facets of this issue. Figure 1 shows a schematic representation of the climate change agenda. This paper identifies key developments in climate change research, proposes measures of enhancing cohesion between research and policy, and concludes with the need for integrated assessment to obtain the goal.

Key developments in climate change research There are four key developments in climate change research. The first development is increasing scientific consensus. Concern about global warming and the influence of human activity, can be traced back to the 1980 s and is reflected in the creation of the Intergovernmental Panel on Climate Change (IPCC), an international attempt to consolidate the scientific community. Their most recent reports, published in 2007, represent international state-of-the-art knowledge on climate change and its likely impacts. Through this forum, the collaborative efforts of scientists have concluded that climate 


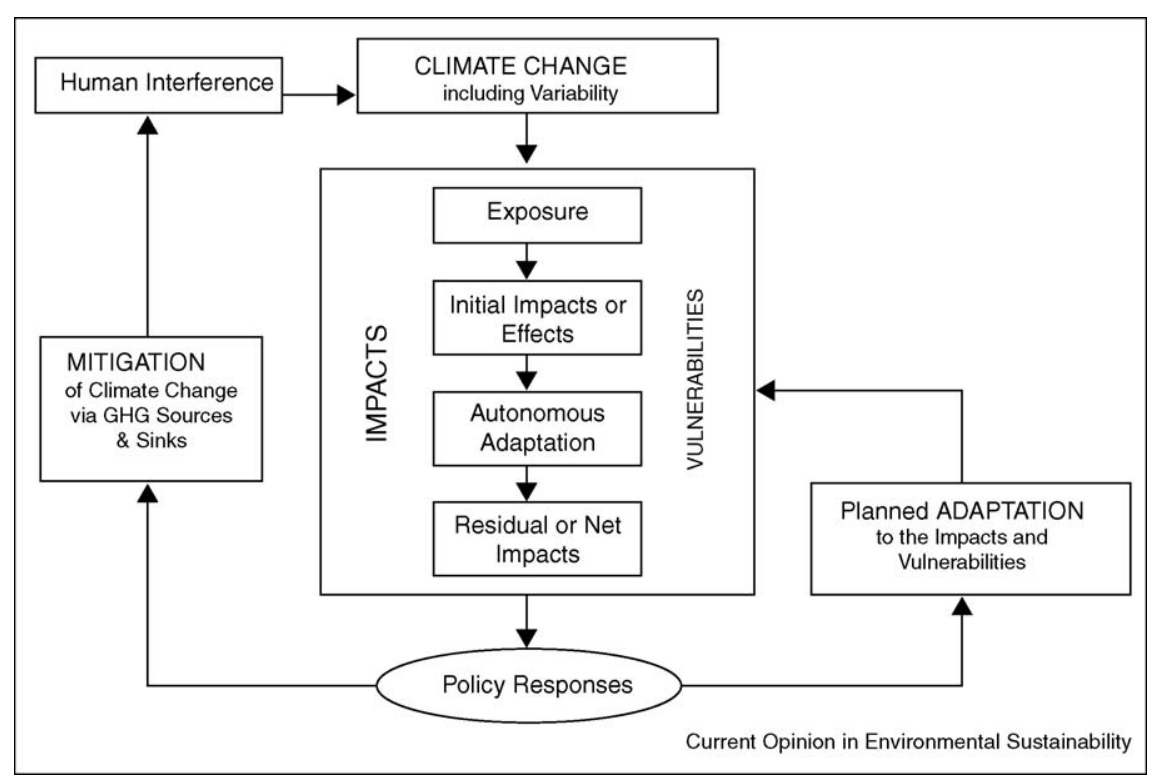

The climate change agenda (derived from [3]).

change is happening, and importantly, that human activity is making a discernible contribution to this change.

The second is a shift of focus from impacts to risk management. Early scientific efforts concentrated on generating knowledge of the potential impacts of a changing climate and how to reduce anthropogenic greenhouse gas emissions. However, since the IPCC's Third Assessment Report in 2001 increasing emphasis has been placed on adaptation and the promotion of a risk management approach. This means going beyond mere consideration of climate-related hazards, to more explicit consideration of issues surrounding the vulnerability and exposure of different elements at risk, as well as addressing conditions of uncertainty. This risk-based approach is embodied in state-of-the-art climate change strategies such as that recently adopted by the Greater London Authority [5].

The third is the consideration of non-climate stressors. When looking to the future it also needs to be recognized that climate-related events will impact on societies that are likely to be very different to today's, hence an integrated assessment of both climate and non-climate scenarios will ultimately be necessary to gain a better understanding of future risks [6].

The fourth, strongly related to the previous three developments, is the recognition of the need for greater interdisciplinary working. While mitigation has dominated policy and research agendas in recent years there is an increasing recognition that actors also need to be preparing for change that is unavoidable. This has resulted in a greater consideration of vulnerability and adaptation. Drawing these different research domains closer together, with improved linkages between natural and social scientists, will be critical to effectively address the complexities of climate change. ${ }^{b}$ New ways of working between scientists, policy-makers, and the wider stakeholder community will also be vital.

\section{Bridging the gap between science and practice}

These advances have also filtered through to the public realm, as reflected in mainstream acceptance of humaninduced climate change and the need for society to respond. Findings from actor-based research carried out for the EU-funded project ADAM (Adaptation and Mitigation: in support of European policy) suggest that, on the whole, the climate change issue is no longer questioned as it was in the past. Across all sectors, there is a common acknowledgment that climate change is happening and that we need to be preparing for future change. Over the past couple of years, there has been increasing recognition that climate change is not merely an environmental issue but is one with important social and economic dimensions as well. This is precisely where multiple disciplines join each other and where science meets policy. This argument received much attention as a result of the Stern report in 2006 [7]. Although not the first economic report on this issue it has become the most widely known

\footnotetext{
b The Dutch NWO-funded VAM program (Vulnerability, Adaptation, Mitigation, and Adaptation-Mitigation) is a contemporary example of an attempt to encourage interdisciplinary working, see: http:/www.nwo.nl/ nwohome.nsf/pages/NWOP_5XDGSK_Eng?OpenDocument.
} 
document of its kind. In it, he provides stark warning that climate change could result in a 'market failure on the greatest scale the world has seen'.

It is also important to recognize that these changes have taken place in a rapidly evolving policy context. Of the two mainstream agendas, mitigation is relatively 'mature' in comparison to adaptation though new instruments continue to be developed and introduced. Perhaps the most high profile of these is carbon trading, a marketbased mechanism given momentum by signing the Kyoto Treaty in 2005. Adaptation on the other hand, can be considered an agenda still very much in its infancy. Nationally, the UK (Adaptation Policy Framework) has perhaps the most advanced program, though other countries such as Finland (FINADAPT) and the Netherlands (ARK) are also developing strategic policy responses. Policy activity is also evident at the supranational scale with the European Commission adopting its first policy document in 2007. A consultation on the Adaptation Green Paper was undertaken in 2008, and the legally binding (though delayed) White Paper was launched in April 2009 [8]. Politically, it is also recognized that there is a need for greater cohesion between climate change and sustainable development objectives. To date, climate change and sustainable development have tended to be treated as two distinct agendas; however, there is considerable added benefit to be gained by ensuring a more coherent approach. Not only will climate change have an adverse impact on progress toward a sustainable future, but also sustainable development activity can reinforce our response to climate change by both enhancing adaptive capacity and increasing resilience. As noted by the IPCC however, few plans for promoting sustainability have explicitly included either adapting to climate change impacts, or enhancing adaptive capacity.

Moves toward considering both types of response as part of a more coherent policy program represents an explicit acknowledgment by decision-makers that both mitigation and adaptation are important in reducing the risks associated with climate change, that is limiting the adverse effects of change and adapting to what is unavoidable. However, even though the preceding text has highlighted clear evidence of a desire to respond to the climate change issue, debate continues as to how best to approach this. Mitigation and adaptation differ in terms of the required capacity, spatial and temporal scale, people's perception, distributions effects, and related stakeholders. These differences in fact provide promising grounds for policy and science to collaborate as well as confronting related disciplines with a need for integration.

First of all, a common link between mitigation and adaptation is the capacity of a system to respond. For example, adaptive capacity can be simply defined as the ability of a system to adjust to climate change; this is thought to be determined by a range of factors including technological options, economic resources, human and social capital, and governance. Mitigation has similar determinants - in particular the availability and penetration of new technology. Although technological solutions have a role to play in both mitigation and adaptation, it should be recognized that 'soft engineering' has a particularly important role in adapting to climate change. The willingness and capacity of society to change is also critical. Information and awareness-raising can be useful tools to stimulate individual and collective climate action [1].

Secondly, an integrated response is challenging as 'mitigation and adaptation are very different in what they mean and how they work'. There is indeed an obvious mismatch in terms of scale, both spatially and temporally. Mitigation efforts are typically driven by national initiatives operating within the context of international obligations, whereas adaptation to climate change and variability tends to be much more local in nature, often in the realm of local/regional economies and land managers. As well as the spatial element, there are also differences in the timing of effects. As greenhouse gases have long residence periods in the atmosphere, the results of mitigation action will only be seen in the longer term. Adaptation, on the other hand, has a stronger element of immediacy [1]. Regional differences and the dynamic feature of vulnerability and averting behavior should therefore be taken into account in both theoretical and practical analyses.

Thirdly, disconnection in space and time can make it difficult for people to link the consequences of their activity with long-term environmental consequences. It also raises the question of environmental equity, that is who are the likely beneficiaries of the different types of response. Mitigation, being an action targeted at the longer term, attaches value to the interests of future generations and to some extent can be considered an altruistic response by society. Conversely, the impacts of climate change are felt more immediately by society and adaptation is typically viewed as everyday 'self-interest' [1]. As such, studies on risk perception by individuals and organizations will be critical to understand the influence on the acceptability and ultimate effectiveness of different responses.

Fourthly, this inevitably leads to a consideration of tradeoffs, in particular who pays and who benefits, and whether there is a willingness to invest if the benefits of climate change response are perceived to be private. It is also important to note discrepancies in that those responsible for the majority of emissions (i.e. developed countries) also have the highest adaptive capacity, while the poorest 
countries, producing the lowest emissions, are most vulnerable to the impacts of a changing climate and this has an influence on the urgency that is attached to any mitigation response. This also holds true within national territories with uninsured, unaware, and relatively immobile populations living in poorer quality accommodation often being hardest hit. In reality, those most vulnerable to climate change are often those already at a socio-economic disadvantage in society [1]. Studies on distributional effects and cost-benefit estimation concerning mitigation, adaptation, mitigation-adaptation measures will contribute to the analyses on tradeoffs.

Lastly, another important difference between mitigation and adaptation relates to those involved. Not only are decisions taken in different policy domains, but also different stakeholder communities are involved. Mitigation policy is primarily focused on decarbonization and involves interaction with the large 'emitting' sectors such as energy and transport, or else targets efficiency improvements according to specific end-users - commercial and residential. The limited number of key personnel and their experience of dealing with long-term investment decisions mean that the mitigation agenda can be considered more sharply defined. In contrast, multiactors involved in the adaptation agenda come from a wide variety of sectors that are sensitive to the impacts of climate change. They also operate at a range of spatial scales. As a result, the implementation of adaptation measures is likely to encounter greater institutional complexity [1]. Research on how formal and informal institutional conditions affect societal vulnerability, adaptive capacity and mitigation choices should therefore not be ignored.

Chapter 18 of IPCG's Fourth Assessment Report [13] explores inter-relationships between adaptation and mitigation and identified the following four types: adaptation actions that have consequences for mitigation, mitigation actions that have consequences for adaptation, decisions that include tradeoffs or synergies between adaptation and mitigation, and processes that have consequences for both adaptation and mitigation. Concerning the analyses of synergies or tradeoffs between adaptation and mitigation, the report suggests considerations of costs/benefits and considerations within regions and sectors. The report suggests improved modeling to be the first step, which has been incorporated in research programs such as VAM in the Netherlands. However, practical measures can be adopted fairly easily. For example, one of the Dutch ARK projects identifies the impacts on mitigation while reviewing each adaptation measure [4]. Several VAM projects examine adaptation and mitigation within specific region or sector. Some government sectors and research institutes have worked more closely on bringing practice and knowledge together. Despite these developments, there is a need for integrating both cost/benefit and regional/sector concerns.

\section{Concluding remarks}

Linking vulnerability, adaptation, and mitigation requires concerns in various perspectives, studies from multiple disciplines, and collaboration between science and policy. Accounting for this complexity, combining different dimensions of climate change, and highlighting the implications for policy and practice, will ultimately require a holistic and integrated approach [10]. The authors suggest that the science of integrated assessment, with its combined application of modeling, scenario, and participatory approaches, has considerable potential for both analysing the multiple causes and impacts of such a complex problem and informing the development of effective policy responses [11]. However, the generation of scientific knowledge alone will not suffice-information will also need to be translated into action 'on the ground'. Hence, as the policy debate moves from one of problemframing to one more concerned with implementation; detailed political, ethical, social, and normative analysis becomes increasingly important. A highly organized inter- and transdisciplinary program of research intended to add value to efforts to improve assessment methodologies, to contribute to the reframing of current scientific understanding, and ultimately to provide new insights into innovative policy options, will be required. Significant scientific and policy challenges remain ahead [12].

\section{Acknowledgements}

We owe our thanks to the Dutch NWO-funded VAM program (Vulnerability, Adaptation, Mitigation, and Adaptation-Mitigation), and the EU-funded project ADAM (Adaptation and Mitigation: in support of European policy).

\section{References}

1. McEvoy D, Lindley S, Handley J: Adaptation and mitigation in urban areas: synergies and conflicts. Proc Inst Civil Eng, Munic Eng 2006, 159:185-191.

2. Wilbanks TJ, Sathaye J: Integrating mitigation and adaptation as responses to climate change: a synthesis. Mitig Adapt Strat Glob Change 2007, 12:957-962.

3. Smit B, Burton I, Klein RJT, Street R: The science of adaptation: a framework for assessment. Mitig Adapt Strat Glob Change 1999, 4:199-213.

4. van lerland EC, de Bruin K, Dellink RB, Ruijs AJW, Bolwidt L, van Buuren A, Graveland J, de Groot RS, Kuikman PJ, Nillesen EEM et al.: A qualitative assessment of climate adaptation options and some estimate of adaptation costs. Routeplanner Projects 3, 4, 5 in ARK Programme. 2007.

5. Greater London Authority: London Climate Change Adaptation Strategy-Draft Report. London: Greater London Authority; 2008. Available at: http://www.london.gov.uk/mayor/publications/2008/docs/ climate-change-adapt-strat.pdf.

6. McEvoy D, Lonsdale K, Matczak P: Adaptation and Mainstreaming of EU Climate Change Policy CEPS Policy Briefing Note for the European Commission. Brussels; 2008 . Available at: http:// shop.ceps.eu/BookDetail.php?item_id=1593.

7. Stern N: The Economics of Climate Change (The Stern Review) Report for the Cabinet Office - HM Treasury. Cambridge: University Press Cambridge; 2006.

8. CEC: Adapting to Climate Change: Towards a European Framework for Action COM 147 Final Brussels: Commission of the European Communities; 2009. 
9. Neufeldt H, Jochem E, Hinkel J, Huitema D, Massey E, Watkiss $P$, McEvoy D, Rayner T, Hof A, Lonsdale K: Chapter 1: Climate policy and the nature of adaptation and mitigation. In Making Climate Change Work for Us: European Perspectives on

Adaptation and Mitigation Strategies. Edited by Hulme M, Neufeldt $\mathrm{H}$. Cambridge University Press; in press.

10. Van Zeijl-Rozema A, Cörvers R, Kemp R, Martens P: Governance for sustainable development: a framework. Sustain Dev 2008, 16:410-421.

11. Martens P: Sustainability: science or fiction? Sustain: Sci Pract Policy 2006, 2:1-5.
12. Kemp R, Martens P: Sustainable development: How to manage something that is subjective and never can be achieved? Sci Pract Policy 2007, 2:1-10.

13. Klein RJT, Huq S, Denton F, Downing TE, Richels RG, Robinson JB, Toth FL: Inter-relationships between adaptation and mitigation. In Climate Change 2007: Impacts, Adaptation and Vulnerability. Contribution of Working Group II to the Fourth Assessment Report of the Intergovernmental Panel on Climate Change. Edited by Parry ML, Canziani OF, Palutiko JP, van der Linden PJ, Hanson CE. Cambridge University Press; 2007: 745-777. 